\title{
In vivo Evaluation of Antimicrobial Effect of Methanolic Extract of Chlorella vulgaris on Impetigo and Some Dermatophytes
}

\author{
M. M. E-Sheekh, Shimaa M. E-Shafay", Enas M. El-Ballat \\ Botany Department, Faculty of Science, Tanta University, Egypt
}

MPETIGO is one of the infectious superficial bacterial diseases and its
treatment with antimicrobial agents may cause serious problems. So, a
test of new microbial infection-fighting natural compounds is necessary. In
the present study, histological examinations of the experimental animals
revealed the effectiveness and safety of Chlorella vulgaris methanolic
extract ointment used in the treatment of impetigo, tinea corporis and
cutaneous candidiasis without any side effects on skin tissues. In addition,
examination of skin sections treated with $C$. Chlorella vulgaris extract
possessed no significant toxic effects. The skin appeared with normal
epidermis as the keratinized fibers of stratum corneum were regularly
arranged, appeared condensed without any disruption. The dermis
appeared normal with minimal inflammatory cellular to infiltrate with
formation of hair follicles and sweat glands in comparison with a healthy
skin. According to the chemical analy ses of Chlorella vulgaris, the
antimicrobial material was defined as a phenolic compound having the
following formula $\mathrm{C}_{14} \mathrm{H}_{17} \mathrm{NO}_{4}$ and the suggested structure could be $2-(1-$
hydroxy-2-(4-hydroxy phenyl)-2- methoxy ethyl - 4 - oxopentane nitrile.

Keywords: Chlorella vulgaris, Antifungal, Antibacterial, Impetigo, Dermatophytes

Infectious diseases are caused by microbes including bacteria, fungi, protozoa, and viruses (WHO, 2010). Synthetic drugs are not only expensive and inadequate for the treatment of diseases but are also often with adulterations and side effects. Therefore, there is a need to search for new infection-combating strategies to control microbial infections (Sieradzki et al., 1999). Pharmaceutical industries are increasingly recognizing the importance of compounds derived from soil plants and other sources such as marine organisms (McGee, 2006).

Algae are a source of amino acids, terpenoids, phlorotannins, steroids, phenolic compounds, halogenated ketones, alkenes and cyclic polysulphides (Taskin et al., 2007). A large number of algal extract products have been found to have antimicrobial activity, many of the structures were identified as fatty acids and hydroxyl unsaturated fatty acids, glycolipid, steroid, phenolics and terpenoids

*Correspondence Author: E-mail address: shimaa.elshafy@ science.tanta.edu.eg. Fax: +20 403350804 . 
(Thillairajasekar et al., 2009). Lauric acid, palmitic acid, linolenic acid, oleic acid, stearic acids are known to be potential antibiotic or antifungal agents (Tan, 2007).

All of humans are colonized by more bacterial cells than human cells they have in their bodies. Generally, this is a peaceful and even productive (symbiotic) relationship, but occasionally even these well-tolerated residents of the human biosphere cause disease (Relman, 2002). Raman et al. (2005) tested chloroformmethanol mixture, n-butanol and diethyl ether extracts of two marine brown algae (Sargassum vulgare and Padina tetrastromatica) from Bay of Bengal near Visakhapatnam sea coast and evaluated for antibacterial activity by agar-well diffusion method. The diethyl ether and chloroform-methanol extracts of $S$. vulgare and diethyl ether, chloroform-methanol and n-butanol extracts of $P$. tetrastromatica exhibited significant antibacterial activity against the 4 tested bacteria namely Escherichia coli, Klebsiella pneumoniae, Bacillus subtilis and Staphylococcus aureus. Moreover, antibacterial activity of methanolic extracts from 20 species of macroalgae (9 Chlorophyta, 3 Phaeophyta and 8 Rhodophyta) collected from Moroccan Mediterranean coasts was evaluated against E. coli, $S$. aureus and Enterococcus faecalis (Zbakh et al., 2012). The extracts of the studied Rhodophyceae inhibited considerably the growth of the three tested bacterial strains. The results indicated that these species of seaweed have a significant capacity of antibacterial activities, which makes them interesting for screening for natural products (Zbakh et al., 2012).

Dermatophytes are a highly specialized group of fungi that, through long evolutionary processes, became adapted to invade, colonize and nourish themselves on the keratinized tissues of animals. Many investigators have shown that these diseases producing moulds possess enzymatic systems that enable them to digest keratins (Weary and Canby, 1969). They affect $20 \%$ to $25 \%$ of the world's population, and the incidence continues to increase (Havlickova et al. 2008). Most cases of tinea unguium, tinea cruris, tinea corporis, and tinea pedis are caused by Tinea rubrum, which is the most common dermatophyte in developed countries (Borman et al., 2007). The phenolic compounds released from dried crudes of seaweed extracts may be answerable for their antimicrobial properties. This was confirmed earlier by Cox et al. (2010) who found that phenolic compounds are responsible for the antifungal activities of seaweeds. This may be due to the impact of these antifungal compounds on spore germination (El-Mehalawy, 2003).

This work aims to study the in vivo effeciency of Chlorella vulgaris methanolic extract to be used in the treatment of impetigo, tinea corporis and cutaneous candidiasis infections.

\section{Alga and Growth conditions}

Chlorella vulgaris (Chlorophyta) was obtained from the culture collection of Botany Department, Faculty of Science, Mansoura University, Egypt. Kuhl's medium (Kuhl, 1962) was used for cultivation of C. vulgaris. The culture was aerated with air mixed with $3 \% \mathrm{CO}_{2}$ and incubated at $28{ }^{\circ} \mathrm{C}$ under continuous

Egypt. J. Bot., 56, No. 2 (2016) 
illumination provided from day light fluorescent tubes giving light intensity of $80 \mu \mathrm{E} \mathrm{m}^{-2} \mathrm{~s}^{-1}$. Chlorella vulgaris was grown and harvested on $12^{\text {th }}$ day. The collected biomass was dried in an oven at $40-60^{\circ} \mathrm{C}$ and then powdered by a mortar.

\section{Algal extracts}

The algal powder of $C$. vulgaris was soaked in $70 \%$ methanol for $5 \mathrm{~h}$ at room temperature and sonicated for $15 \mathrm{~min}$. algal extract was filtered through Whattman filter paper No.1. The obtained filtrate was freed from solvent by evaporation under reduced pressure. The obtained residues (crude extracts) were suspended in methanol to a final concentration of $50 \mathrm{mg} / \mathrm{ml}$. The extract was stored in the refrigerator in airtight glass bottle for further experiments.

\section{Isolation and culture techniques of pathogenic microorganisms}

Samples were collected from patients clinically diagnosed to have impetigo, tinea corporis and cutaneous candidiasis under aseptic conditions. Prior to sampling, the affected area surface was cleaned with cotton swab moistened with $70 \%$ ethyl alcohol. Different parts on mouse, near nose, arms and legs (for impetigo samples), legs and arms (for tinea corporis and cutaneous candidiasis samples), cotton swabs, tubes of phosphate buffered saline, glass slides and Petri dishes were previously sterilized to be used in sampling. Sterile scalpel was used to collect skin scrapings on sterile glass slide (El-Shanawany, 1993). The collected samples were isolated in a closed controlled room in hospitallaboratory.

For the impetigo samples

Samples were forwarded to the Bacteriology Laboratory in $2 \mathrm{ml}$ phosphatebuffered saline (PBS) composed of $\mathrm{NaCl}, 8 \mathrm{~g} / \mathrm{L} ; \mathrm{KCl}, 0.2 \mathrm{~g} / \mathrm{L} ; \mathrm{Na}_{2} \mathrm{HPO} 4$, $1.15 \mathrm{~g} / \mathrm{L}$; and $\mathrm{KH}_{2} \mathrm{PO}_{4}, 0.2 \mathrm{~g} / \mathrm{L}$. All culture swabs were processed in the same day that they were collected. Each specimen was plated to mannitol salt agar medium . Culture plates were incubated up to $24 \mathrm{hr}$ at $37^{\circ} \mathrm{C}$ (Gheda et al, 2012).

For the tinea corporis and cutaneous candidiasis samples

Each sample was cultured in three sterilized Petri dishes containing sterile Sabouraud's dextrose agar (SDA) medium; each 1 liter of distilled water contained $30 \mathrm{~g}$ dextrose, $10 \mathrm{~g}$ peptone, $20 \mathrm{~g}$ agar, and $0.5 \mathrm{~g}$ from each chloramphenicol and cycloheximide were added to avoid bacterial contamination (Al Doory, 1980). Plates were incubated at $37^{\circ} \mathrm{C}$ for $7-20$ days for dermatophytes and for 2-3 days for Candida albicans.

\section{Treatment of impetigo and dermatophytes in experimental animal}

Healthy albino rats of average weight of $120 \mathrm{~g}$ were processed and placed in animals' house, Zoology department, Faculty of Science, Tanta University. Fresh isolates of Staphylococcus aureus, Microsporum canis and Candida albicans were utilized to perform artificial infections with the pathogens. The rats were infected with the different pathogens after producing the thermal lesion on its back as follows: after anaesthetization of the animal, a pre-heated brass blocks $\left(92-95{ }^{\circ} \mathrm{C}\right)$ to the backs of the shaved rate for $5 \mathrm{sec}$. After the infliction of burns, the eschars were immediately injected intradermally with $10^{6} \mathrm{CFU}$ of all pathogens (Stevens et al., 1994). The infection repeated daily and the rats were 
left a time to allow the infection to form a definite lesion which appeared after 5 days for bacteria and after two weeks for fungi.

Chlorella vulgaris ointment was prepared from its extract and the topical cream was carried out according to Purushothamrao et al. (2010). The prepared cream was applied on the lesion separately twice a day (5 rats for cream treatment) for a total period of one week for the bacterial infection and two weeks for the fungal infection. Positive control of ciclopirox and nystatin creams were applied for 5 infected rats as antifungal agent for 5 rats, while mupirocin was applied as antibacterial for another 5 rats. Als o, negative control was conducted by leaving the infection lesion without treating.

\section{Histopathological examinations of rat's skin tissues}

Histopathological examination was carried out for 4 groups of rats. The first one was for healthy rat's skin tissue as a positive control. The second was for infected rat's skin tissues with impetigo and dermatophytes (untreated) as a negative control. The third was for infected rat's skin tissues treated with algal extract ointment. The last group was for infected rat's skin tissues treated with mupirocin, ciclopirox and nystatin. Skins were cut using a sterile surgical blade and immediately soaked in $10 \%$ formaldehyde fixative solution, and left for $24 \mathrm{hr}$. Skin samples were soaked in $95 \%$ ethanol with traces of eosin dye to be distinguished, then clarified by soaking in xylene (miscible with paraffin) to avoid turbidity of ethanol. Skin samples were transferred into molten soft paraffin bath. Sections of $5 \mu \mathrm{m}$ thickness were made from paraffin blocks containing skin samples by rotary microtome with clean sharp heated biconcave knife (AlconCouvreur, Belgium), and then the skin sections were stained. The skin sections were examined using light microscope, sharp images were photographed with magnification power of (200x and/or 400x).

Chemical analysis of $C$. vulgaris extract

Determination of the chemical structure of antimicrobial material

A. Mass spectra $(M S)$ of the antimicrobial material

A mass spectrophotometer (Shimadzu Qu-2010 Plus) was used for subjection of the compound to a stream of high energy of electrons at elevated temperature up to $100{ }^{\circ} \mathrm{C}$. The produced fragments were yielded which can be characterized by mas slcharge from spectra data.

B. Proton nuclear magnetic resonance $\left({ }^{1} H N M R\right)$ spectra

The sample was dissolved in dimethyl sulfoxide (DMSO). The different protons of functional groups were identified using NMR (Varian Gemini 200 MHZ).

\section{Results}

Albino rats were infected with fresh isolates of Staphylococcus aureus, Microsporum canis and Candida albicans. The inoculation area was shaved as in photos (Photo .1.a) and burned as shown in photo (Photo 1.b). The infection began on the stratum corneum by allowing contact of pathogens cells of $S$. Egypt. J. Bot., 56, No. 2 (2016) 
aureus, $M$. canis and $C$. albicans on the skin of the rats. The infection of impetigo, tinea corporis and candidiasis appeared. The symptoms of scaly lesions were observed with inflammation appeared at the infected area as in (Photos 1.c1, 2, 3). After complete establishment of the lesions, the following treatments were applied; first, ointment preparation of $C$. vulgaris extract that possesses a high inhibitory effect on $S$. aureus, $M$. canis and $C$. albicans was applied separately on the infected lesions of rats skin. Second, mupirocin, ciclopirox and nystatin creams were applied separately on the infected lesions of other infected rats. Sections from the rats under treatment showed the healing process and examining the changes in the layers of skin.

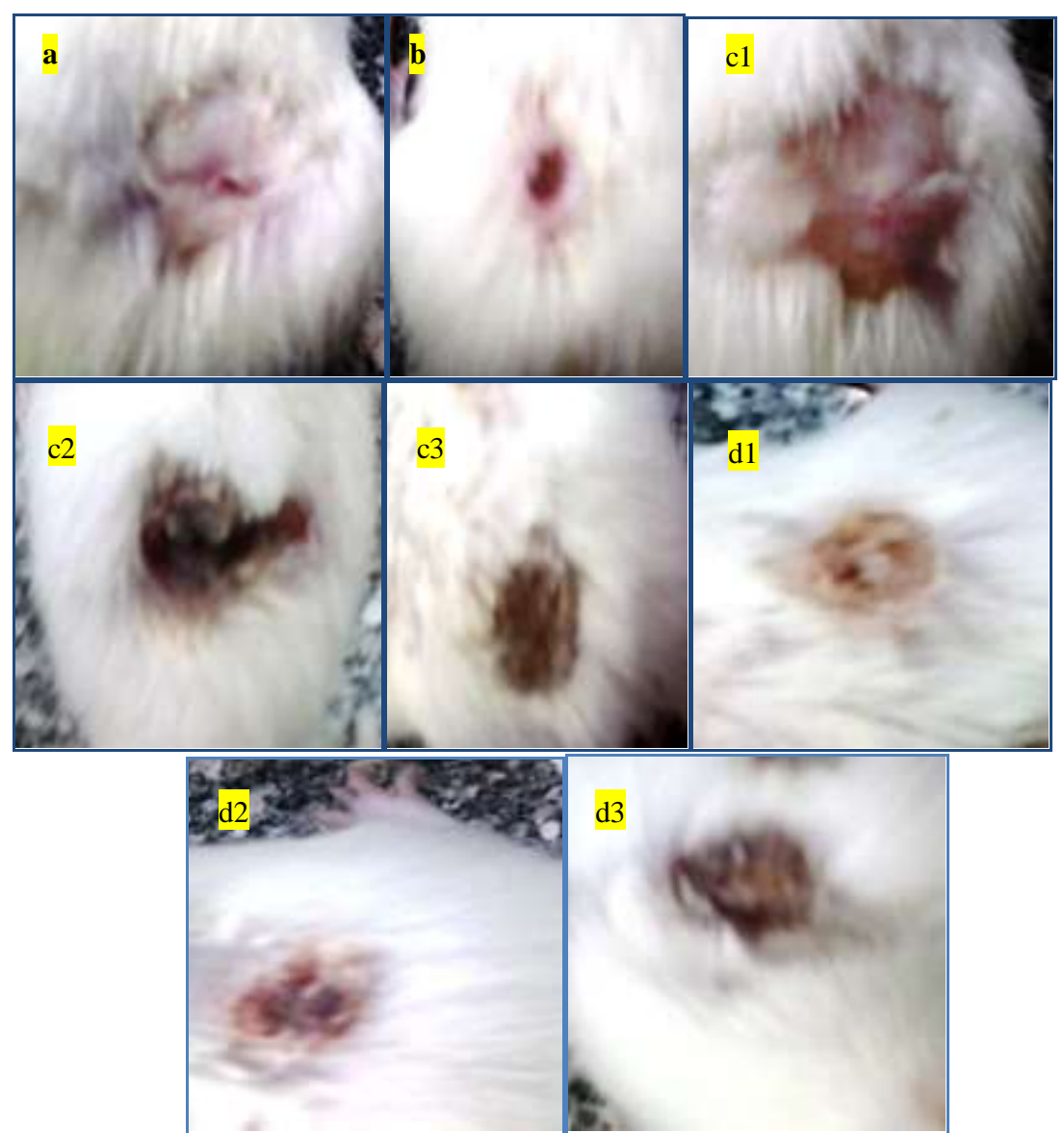

Photo 1. In vivo healing of Staphylococcus aureus, Microsporumcanis and Candida albicans growth in rat's impetigo, tinea corporis and candidiasis lesions at different stages: Control: a: Non-infected, non-treated rat skin, b: Non-infected, non-treated, burned rat skin,

c: Infected, non-treated rat skin with high occurrence of lesions
1-S. aureus
2-M. canis
3- C. albicans
d: Infected rat skin after 4 days of treatment,
2-S. aureus 2-M. canis 3-C. albicans

Egypt. J. Bot., 56, No. 2 (2016) 
The treatment was very effective after one week of treatment of impetigo as shown in Photo 1.e1 and partial healing of skin infected by fungi appeared as shown in Photos 1.e2, 3, while after two weeks the hairs appeared again in the rats infected with bacteria as shown in Photo 1.f1 and the complete healing of the fungal infections appeared as shown in Photos .1.f 2,3. Our study revealed that the treatment with mupirocin, ciclopirox and nystatin after one and two weeks, respectively, illustrates partially cure of lesions and inflammation.

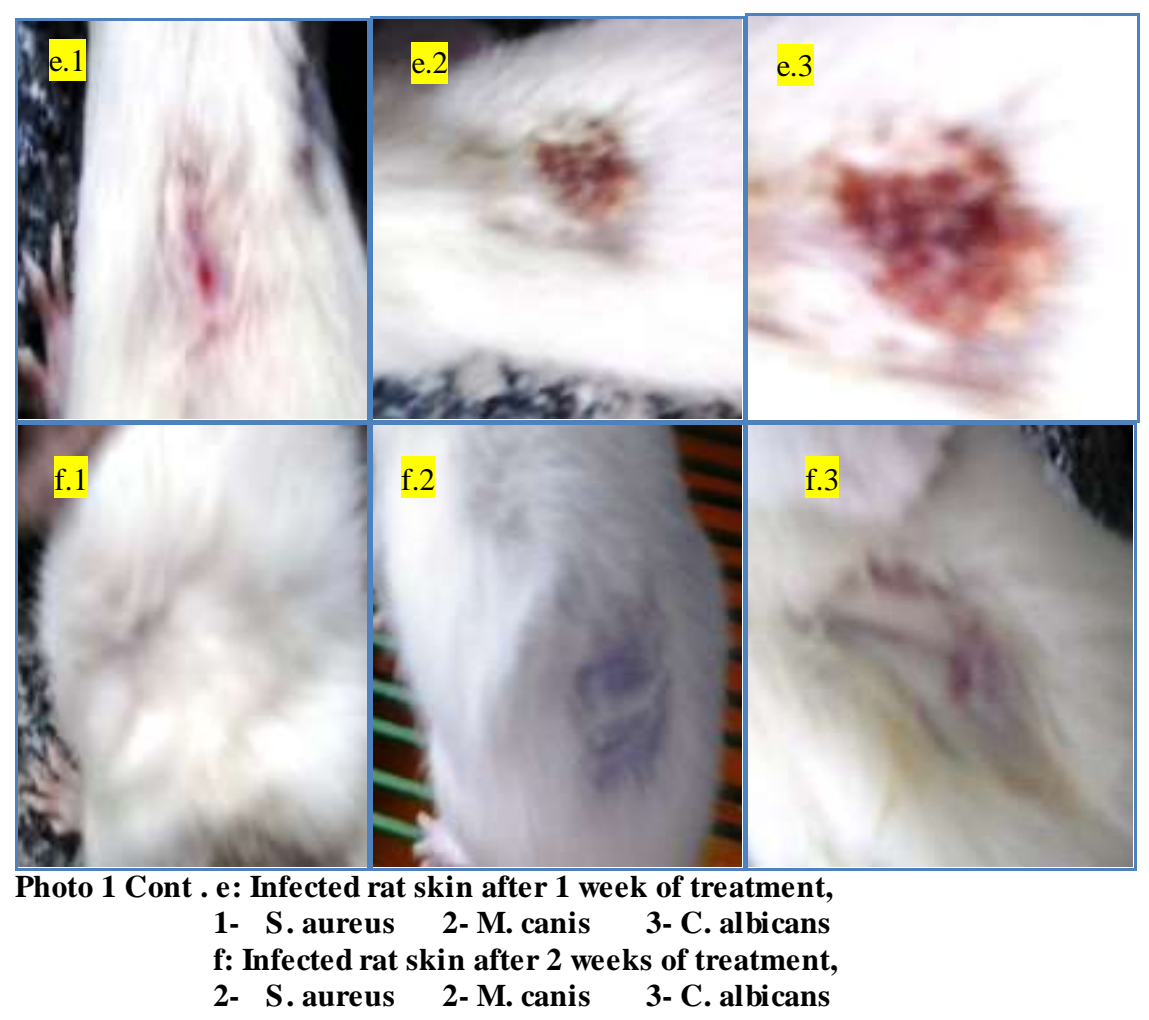

Improvement tests for C. vulgaris extract effectiveness and safety to be used in topical treatment for impetigo and fungal infections were achieved by histopathological studies (Photo 2). Skin sections for healthy rat skin tissues showed normal histological pattern; normal epidermis (Ep) as the keratinized fibres of stratum corneum $(\rightarrow)$ were regularly arranged, appeared condensed without any disruption and the dermis (D) appeared normal which formed of two layers; papillary and reticular layer with normal fibroplasts, hair follicles, sebaceous glands in papillary layer and sweat glands. The reticulate layer appeared with many fat cells as shown in (Photo .2.a). Skin tis sues of the infected rats (untreated) showed; in case of the bacterial infection, partial losing of the epidermis layer with lost, disrupted stratum corneum layer $(\rightarrow)$ and the dermis showed inflammatory cellular infiltrates $\left(^{*}\right)$ mainly formed of lymphocytes and plasma cells as shown in (Photo .2b.1).However, in case of the fungal infections, 
the infection caused by Microsporum canis showed scap (S) covering the upper part of lesion, and the thickness of the underling epithelium is apparently smaller $(\rightarrow)$ than the epithelial layer of the normal part in the same section as shown in (Photo 2.b.2). The infection caused by Candida albicans showed abnormal histological pattern of skin; as the dermis showed infiltration $(*)$ and loss of the hair follicles (?) as shown in (Photo 2.b.3).
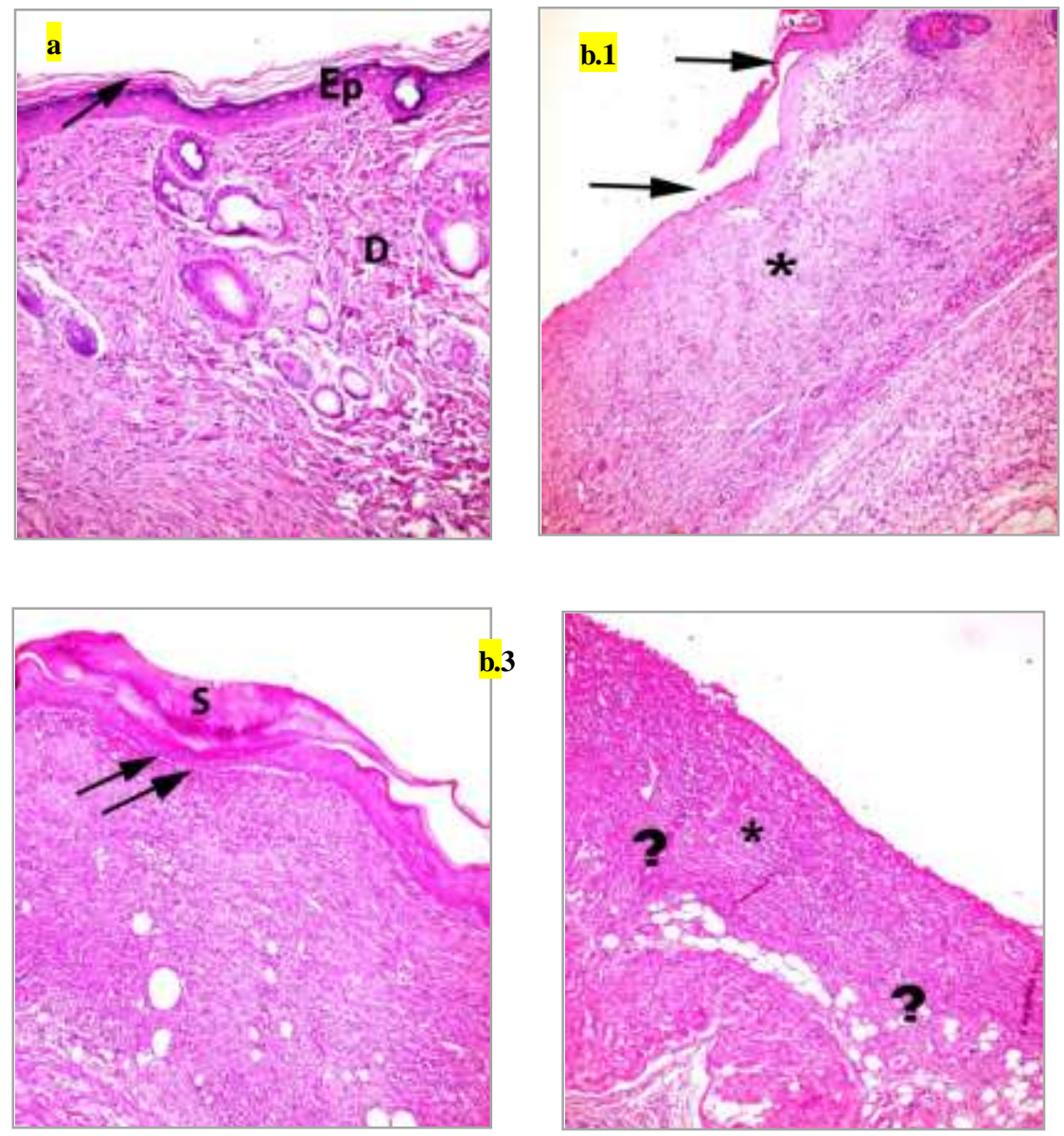

Photo 2. Histopathological effects of Chlorella vulgaris extract treatment for impetigo, tineacorporis and candidiasis infections on rat's skin lesions against mupirocin, ciclopirox and nystatin;

a- Negative control: healthy skin,

b- Positive control: infected non-treated skin, 1-S. aureus 2-M.canis 3-C.albicans

During the period of treatment, the healing of skin appeared gradually and the histological effects of $C$. vulgaris extract treatment were followed up periodically. The skin returned to its normal pattern in a short time and the skin 
tissues appeared with normal epidermis as the keratinized fibres of stratum corneum were regularly arranged $(\rightarrow$ ) appeared condensed without any dis ruption and the dermis appeared normal with minimal inflammatory cellular infiltrate $(*)$ as shown in (Photo .2.c). On the other hand, mupirocin-treated skin sections showed normal epidermis with apparently normal thickness, the thickness of stratum corneum layer appeared normal in a part of section but appeared thin $(\rightarrow)$ in another part in the same section. Regarding to the dermis; it still loses the hair follicles (?) as shown in (Photo .2.d). Ciclopirox- and nystatintreated skin section possessed stratum corneum was still lost $(\rightarrow)$, separation of epidermis and the dermis ( ) showed exudates with some inflammatory cellular infiltrate of lymphocytes, vacuolation of keratinocyte or epidermal cells $\left(^{*}\right)$ as shown in (Photo 2.e).
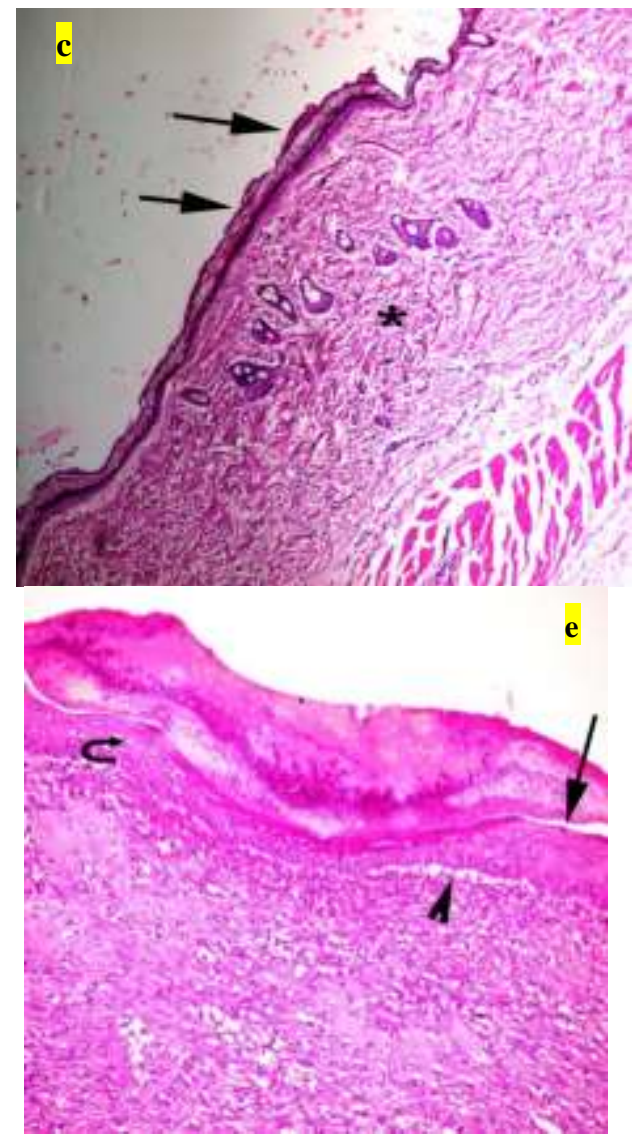

Photo 2. (Cont.) Histopathological effects of Chlorella vulgaris extract treatment for impetigo, tinea corporis and candidiasis infections on rat's skin lesions against mupirocin, ciclopirox and nystatin;

a. C. vugaris-treated, healed skin,

b. Mupirocin-treated, partially healed skin,

c. Ciclopirox- and nystatin -treated, partially healed skin.

Egypt. J. Bot., 56, No. 2 (2016)

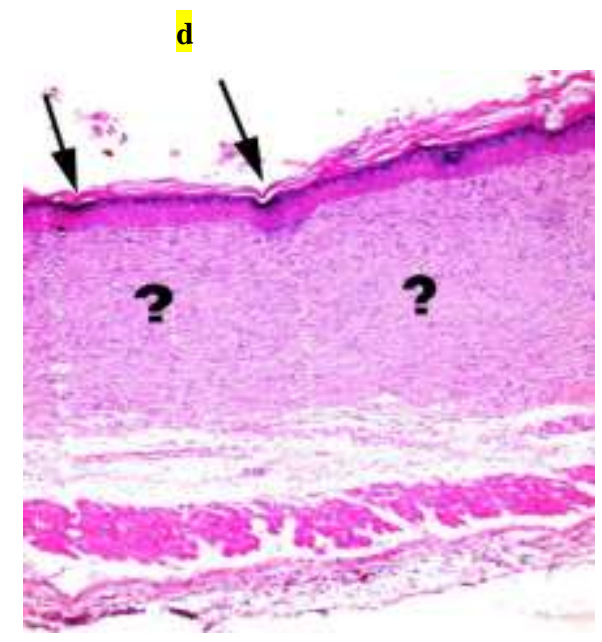


In the present study, NMR and Mass spectra data was used to elucidate the chemical structure of the antimicrobial material extracted from $C$. vulgaris. The characteristic signals in the NMR spectrum were represented graphically in Fig. 1. The NMR spectrum showed two signals at $\delta 8.0-8.4 \mathrm{ppm}$ which are characteristic of the $4 \mathrm{H}$ aromatic protons. The two signals within $\delta 4.5-4.7 \mathrm{ppm}$ range corresponding to $2 \mathrm{OH}$ groups. The signals within $\delta 2.5-2.7 \mathrm{ppm}$ range are characteristic of the protons of the $\mathrm{CH}$ group. The signals at $\delta 1.9-2$ ppm region are characteristic of the protons of the $\mathrm{OCH}_{3}$ group. The $\mathrm{CH}_{3}$ group leads to a broad signal at $\delta 1.7 \mathrm{ppm}$ with integration equivalent to one proton.

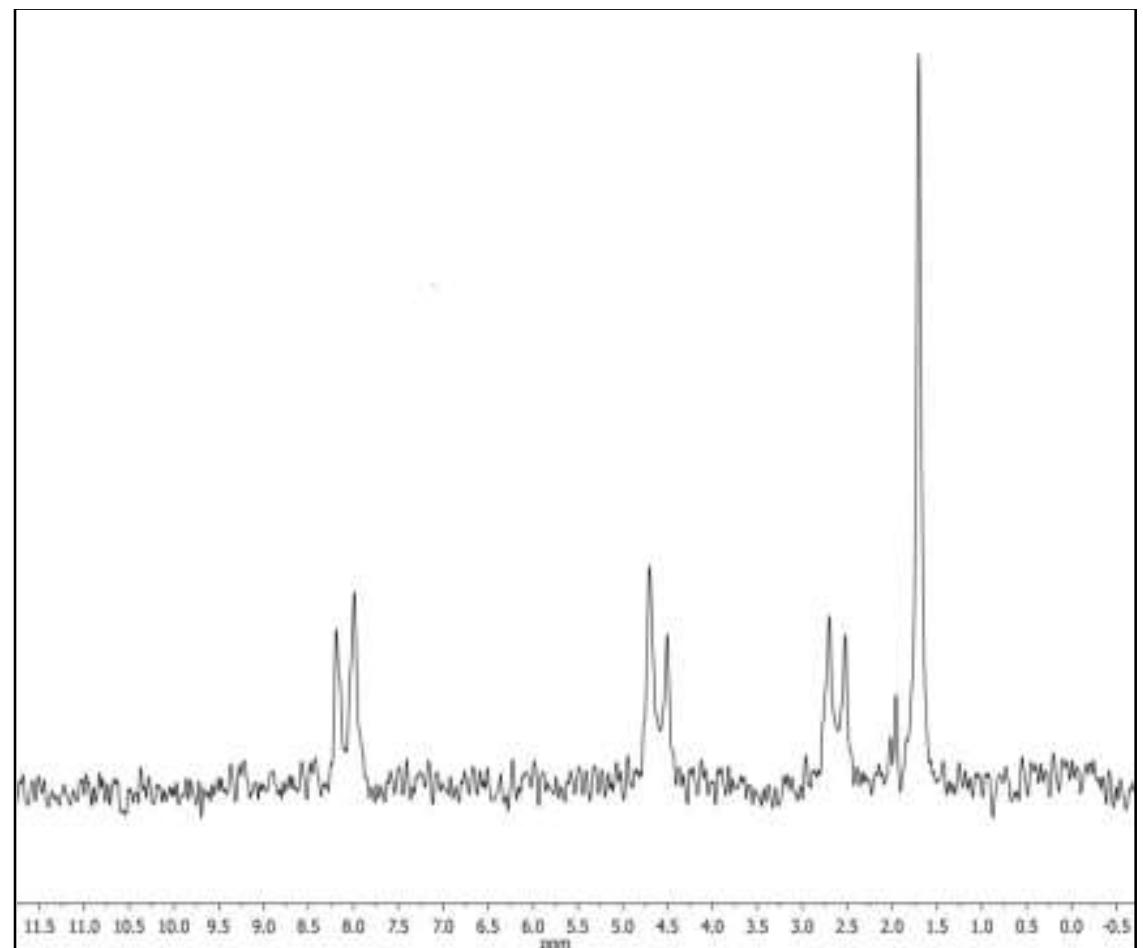

Fig. 1. Proton magnetic resonance of the antimicrobial material isolated from Chlorella vulgaris.

The mass spectrum (MS) fragmentation pattern of the compound under investigation was shown in Fig. 2. It revealed the presence of peak at $\mathrm{m} / \mathrm{z} 263$ of relative abundance characteristic of the parent compound.

According to the data obtained, the antimicrobial material is a phenolic compound having the following formula $\mathrm{C}_{14} \mathrm{H}_{17} \mathrm{NO}_{4}$ and the suggested structure should be 2-(1-hydroxy-2-(4-hydroxyphenyl)-2-methoxyethy 1-4-oxopentanenitrile. The mass spectroscopy of our antifungal material indicated that the molecular weight is 263 (Fig. 3). 


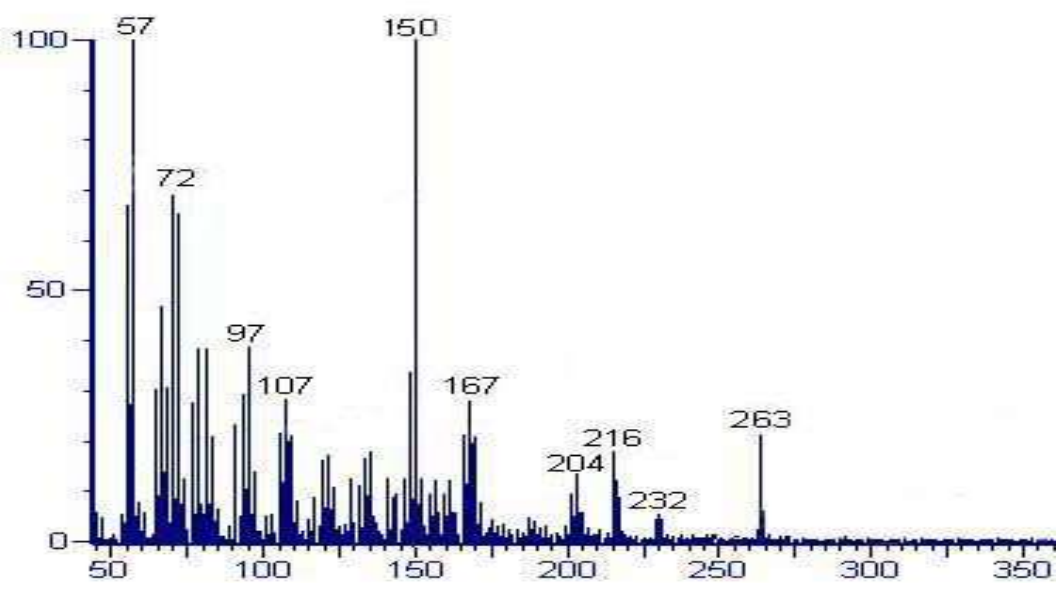

Fig. 2. Mass spectra of the antimicrobial material isolated from Chlorella vulgaris.

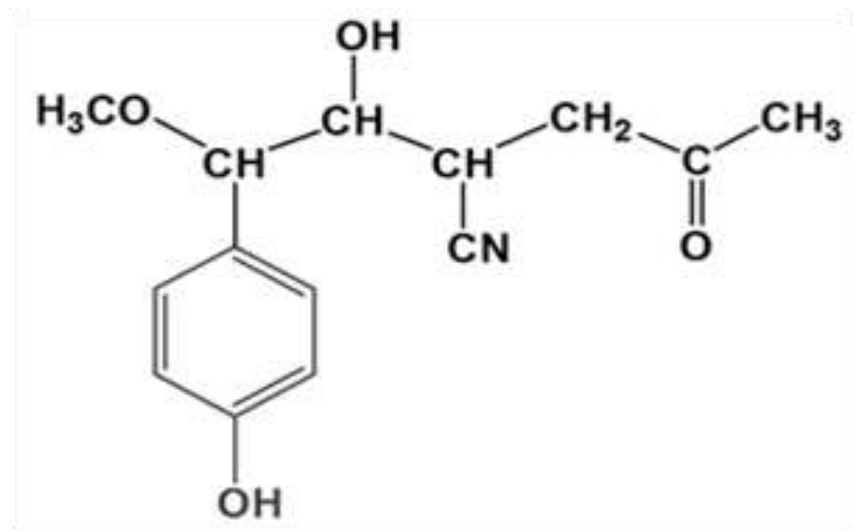

Fig. 3. The suggested chemical structure of the purified antimicrobial material isolated from Chlorella vulgaris.

\section{Discussion}

This study confirmed the high activity of $C$. vulgaris methanolic extract at low concentration. Results confirmed that it would treat the impetigo and skin fungal infections as Candidiasis and tinea corporis. Most researchers have attributed the degradation of keratinic substrates to the production of specific and mostly extracellular proteolytic enzymes called keratinases, whose secretion appears to be induced by the presence of keratin in the substrate (Apodaca and McKerrow, 1989; Siesenop and Böhm, 1995). However, those secreted by T. rubrum appear to be responsible for keratinolysis (Kwon-Chung and Bennet, Egypt. J. Bot., 56, No. 2 (2016) 
1992). Extracellular keratinases are produced by bacteria (Böckle et al., 1995; Lin et al., 1995) and fungi (Siesenop and Böhm, 1995; Lambkin et al., 1996). Roberts (1996) reported that the production of enzymes such as phospholipase, lipase and keratinase by the invading fungus could lead to damage of keratinocytes and affect melanocytes causing changes in skin structure. So, these enzymes may help in the passage of fungi to stratum conium of skin by physical barriers and other layers of skin and this could be a reason of tis sue damage (Howard, 1983).

Virulence of pathogenic fungi depending on keratinolytic activity was confirmed by analysis of virulence factors (Viani et al., 2001) as fungal pathogenesis was proved by keratinase production, which was characterized and purified from Microsporum canis. Many filamentous fungi can synthesize a diverse range of hydrolytic enzymes such as proteases and lipases (Weitzman and Summerbell, 1995). However, keratinases are the key enzymes in fungal invasion of skin and have been mostly studied in dermatophytes, including Trichophyton sp., Microsporum sp., some pathogenic yeasts such as $C$. albicans and some other fungi and bacteria (Okafur and Ada, 2000; Muhsin and Hadi, 2002). Gheda et al. (2012) tested the antibacterial activity of Spirulina platensis for the treatment of patients infected by impetigo, and they reported that in vivo application of both active ingredients and crude extracts of Spirulina platensis showed promising response rates, and no side effects appeared during the follow-up period.

The chemical analys es of algal extract by methanol showed the presence of active phenolic compounds. Vepritski et al. (1991) also reported that cyanobacterin LU-2 produced by Nostoc sp. is a phenolic derivative containing amino-sugar. The produced antimicrobial material is effective against fungi, which was agreed with that reported by De cano et al. (1990) who observed inhibition of C. albicans by phenolic compounds from N. muscorum and Chlorella sp. The mass spectroscopy of our antimicrobial material indicated that the molecular weight is 263. Glombitza and Damhues (1985) studied the chemical structure of 17 oligomericphloro-tannins is olated from the brown alga Himanthalia elongate using ${ }^{1} \mathrm{H}$ NMR and mass spectra. Sastry and Rao (1994) identified the antimicrobial compound isolated from $S$. wightii as dioctyl phthalate. The structure was confirmed from spectroscopic data $\left({ }^{1} \mathrm{H}\right.$ and $\left.{ }^{13} \mathrm{C} \mathrm{NMR}\right)$, which were compared with data obtained from authentic samples. Jaki et al. (2000) determined the structure of five novel extracellular di-terpenoids with biological activity from the cyanobacterium $N$. commune by spectroscopic methods, mainly NMR and MR. Furthermore, Jaki et al. (2001) determined the structure of two novel cyclic peptides with antifungal activity from the cyanobacterium Tolypothrix by 1D and 2D NMR experiments and tandem mass spectrometry.

\section{Conclusion}

The results of this investigation showed that the methanol extract of C. vulgaris used as natural ointment was effective against bacterial and fungal skin infections. The histological examinations of rat's skin tissues revealed the fast healing of the skin layers and showed normal histological patterns of rat skin, while the synthetic ointments showed partial healing comparing with the natural 
product from $C$. vulgaris extract ointment. The chemical analysis suggested the chemical formula of the antifungal substance as $\mathrm{C}_{14} \mathrm{H}_{17} \mathrm{NO}_{4}$ and the suggested structure should be 2-(1-hydroxy-2-(4-hydroxyphenyl)-2-methoxyethyl-4oxopentanenitrile.

\section{References}

Al Doory, Y. (1980) "Laboratory Medical Mycology". Lea \& Febiger philadilphia kimpton publishers, London.

Apodaca, G. and McKerrow, J. (1989) Regulation of Trichophyton rubrum proteinolytic activity. InfectImmunol., 57, 3081-3090.

Böckle, B., Galunsky, B. and Müller R. (1995) Characterization of a keratinoly tic serine proteinase from Streptomyces pactum DMS-40530. Appl. Environ. Microbiol., 61, 3705-3710.

Borman, A.M., Campbell, C.K., Fraser, M. and Johnson, E.M. (2007) Analy sis of the dermatophyte species isolated in the British Isles between 1980 and 2005 and review of worldwide dermatophyte trends over the last three decades. Med. Mycol., 45, 131141.

Cox, S., Abu-Ghannam, N. and Gupta, S. (2010) An assessment of the antioxidant and antimicrobial activity of six species of edible Irish seaweeds . Int. Food Res. J., 17, 205-220.

De Cano, M.S., De Mule, M.Z., De Caire, C.Z. and De Halperin, D.R. (1990) Inhibition of Candida albicans and Staphylococcus aureus by phenolic compounds from the terrestrial cy anobacterium Nostoc muscorum . J. Appl. Phycol., 1(2), 79-82.

El-Mehalawy, A.A. (2003) A comparison between the effect of fungicide 'saprol' and the biocontrol agent trichodermaviride on the pathogenicity and metabolism of the plant pathogenic fungus alternariasolani. Egypt. J. Biotechnol., 13, 202-211.

El-Shanawany, A.A. (1993) Human dermatophytes in Assiut and new Valley Governorates. Ph.D. Thesis, Bot. Dept., Fac. Sci., Assiut Univ., Egy pt.

Gheda, S.F., Khalil, M.A. and Gheida, S.F. (2012) In vitro and in vivo preliminary results on Spirulina platensis for treatment of impetigo: topical cream application. African Journal of biotechnology, 12(18), 2498-2509.

Glombitza, K.W. and Damhues, J.G. (1985) Antibiotics from algae XXXIII: Phorotannins of the brown alga Himanthalia elongate. Planta Med., 11, 42-46.

Havlickova, B., Czaika, V.A. and Friedrich, M. (2008) Epidemiological trends in skin my coses worldwide. Mycoses, 51(4), 2-15.

Howard, D.H. (1983) Fungi Pathogenic for Humans and Animals. Inc., New Yourk, 18, 267-271. 
Jaki, B. Orjala, J. Heilmann, J. Linden, A. Vogler, B. and Sticher, O. (2000) Novel extracellular diterpenoid with biological activity from the cyanobacterium Nostoc commune.J. Nat. Prod., 63(3), 339-343.

Jaki, B. Zebre, O. Heilmann, J. and S ticher, O. (2001) Two novel cy clic peptides with antifungal activity from the cyanobacterium Tolypothrix byssoidea (EAWAG 195). J. Nat. Prod., 64(2), 154-158.

Kuhl, A. (1962) Zur Physiologie der Speicherung kondersierter anorganischer phosphate in chlorella.vortr. botan. hrsg. Deut. botan. Ges., 1, 157-166.

Kwon-Chung, K.J. and Bennet, J.E. (1992) "Medical Mycology". Philadelphia London, Lea \&Febiger.

Lambkin, I., Hamilton, A.J and Hay, R.J. (1996) Purification and characterization of a novel 34.000-MR cell-associated proteinase from the dermathophyte Trichophyton rubrum. FEMSImmunol. Med. Microbiol., 13, 131-140.

Lin, W., Kelemen, D.W., Miller, E.S. and Shih, J.H. (1995) Nucleotide sequence and expression of KerA, the gene encoding a keratinolytic protease of Bacillus licheniformis PWD-1. Appl Environ Microbiol., 61, 1469- 1474.

McGee, P. (2006) Natural products re-emerge. Drug Disc. Develop, 9, 18-26.

Muhsin, T.M. and Hadi, R.B. (2002) Degradation of keratin substrates by fungi isolated from sewage sludge. Mycopathologia, 154 (4), 185-189.

Okafur, J.I. and Ada, N. (2000) Keratinolytic activity of five human isolates of the dermatophytes. J. Commun. Dis., 32 (4), 300-305.

Purushothamrao, K. Khaliq, K. Sagare, P. Patil, S.K. Kharat, S.S. and Alpana, K. (2010) Formulation and evaluation of vanishing cream for scalp psoriasis. Int. J. Pharm. Sci. Tech. 4(1).

Raman, B.V., Radhakrishnan, T.M. and Rajagopal, S.V. (2005) Antibacterial and immune modulatory studies of selected brown algae of Visakhapatnam seacoast. Indian Journal of Microbiology, 45(3), 241-244.

Relman, D.A. (2002) The human body as microbial observatory. Nat. Genet., 30,131-133.

Roberts, S.O.B. (1996) Pitrysporumorbiculare: Incidence and distribution on clinically normal skin. Br. J. Derm., 81, 259-264.

Sastry, V.M. and Rao, G.R. (1994) Antibacterial substances from marine algae: successive extraction using benzene, chloroform and methanol. Bot. Mar., 37, 357-360.

Stevens, E.J. Ryan, C.M. Friedberg, J.S. Barnhill, R.L. Yarmush, M.L. and Tompkins, R.G. (1994) A quantitative model of invasive Pseudomonas infection in burn injury. J. Burn Care Rehabil., 15(3), 232-235.

Sieradzki, K.W. Roberts. R.P. Haber, S.W. and Tomasz, A. (1999) Inactivation of the methicillin resistance gene mecA in vancomycin-resistant Staphylococcus aureus. Micro.Drug. Resist. 5, 253-257. 
Siesenop, U. and Böhm, K.H. (1995) Comparative studies on keratinase production of Trichophyton mentagrophytes strains of animal origin. Mycoses, 38, 205- 209.

Tan, L.T. (2007) Bioactive natural products from marine cyanobacteria for drug discovery. Phytochem , 68, 954-79.

Taskin, E., Ozturk, M., Taskin, E. and Kurt, O. (2007) Antibacterial activities of some marine algae from the Aegean Sea (Turkey). Afr. J. Biotechnol., 6, 2746-2751.

Thillairajasekar, K., Duraipandiyan, V., Perumal, P. and Ignacimuthu. S. (2009) Antimicrobial activity of Trichodesmiumery thraeum (Ehr.) (microalgae) from South East coast of Tamil Nadu, India. Int. J. Integr. Biol., 5(3), 167-170.

Vepritski, A.A., Gromov, B.V., Titova, N.N. and Mamkaeva, K.A. (1991) Production of the antibiotic - algicide cyanobacterin $\mathrm{Lu}-2$ by a filamentous cyanobacterium Nostoc sp. Mirrobiologica, 60(6), 21-25.

Viani, F.C., Dos, J.I., Paula, C.R., Larson, C.E., and Cambale, W. (2001) Production of extracellular enzymes by Microsporum canis and their role in its virulence. Med. Mycol., 39, 463-468.

Weary, P.E. and Canby, C.M. (1969) Further observations on the keratinolytic activity of Trichophyton schoenleinii and Trichophyton rubrum. J. Invest. Derm., 53, 58-63.

Weitzman, I. and Summerbell, R.C. (1995) The dermatophy tes Clin.Microbiol. Rev., 8, 240-259.

WHO (2010) Infectious disease. (Accessed on May 2014).

Zbakh, H., Chiheb, H., Bouziane, H., Sánchez, V.M. and Riadi, H. (2012) Antibacterial activity of benthic marine algae extracts from The Mediterranean Coast Of Morocco. Journal of Microbiology, Biotechnology and Food Sciences, 2(1), 219-228. 


\section{تقيم تطبيقى لتأثير المضاد الميكروبية لمستخلص الميثانولى الميلى مـن طلب الكلوريلا فولجاريس على مرض الكريك الحصف الجلدي و بعض الأمر اض الفطرية}

$\Delta I$

مصطفى محمد الثيخ ، شيماء محمد الثـافعى و إيناس مصطفى البلاط

قسم النبات - كلية العلوم - جامعة طنطاعل - مصري

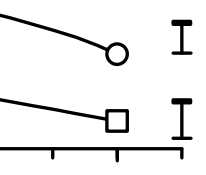

10

بعض الامر اض الجلديه مثل مرض الحصف الجلدى (من الامراض البكتيرية)

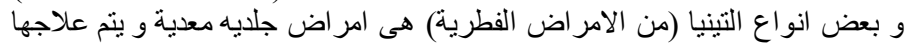

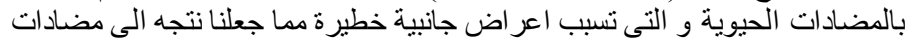

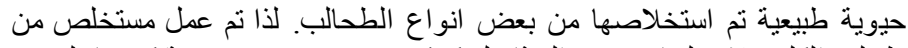

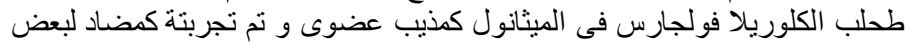

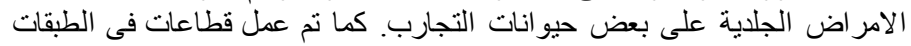

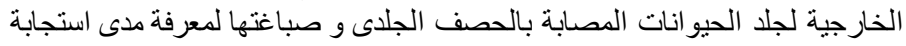
الجلد للعلاج بمستخلص الطحالب و مقارنته بالمضادات الحيوية المستخدمة طبيا.

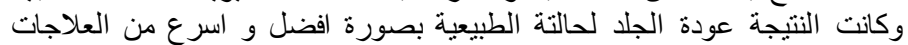

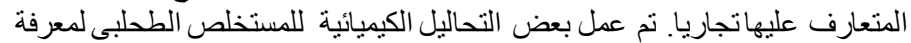

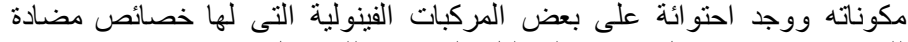

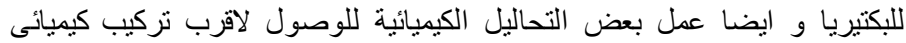

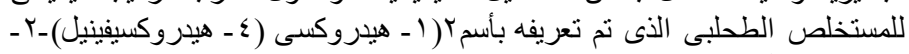

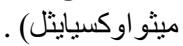

